\title{
Fe(III)-Lipoxygenase Converts Its Suicide-Type Inhibitor Octadeca-9,12-diynoic Acid into 11-Oxooctadeca-9,12-diynoic Acid
}

\author{
Willem F. Nieuwenhuizen, ${ }^{\ddagger}$ Maria J. Schilstra, ${ }^{\ddagger}$ Anca Van der Kerk-Van Hoof, ${ }^{\S}$ Lambert Brandsma,", \\ Gerrit A. Veldink, ${ }^{*}, \frac{\neq}{+}$ and Johannes F. G. Vliegenthart \\ Bijvoet Center for Biomolecular Research, Department of Bio-Organic Chemistry, Utrecht University, Padualaan 8 , \\ 3584 CH Utrecht, The Netherlands, Bijvoet Center for Biomolecular Research, Department of Biomolecular Mass Spectrometry, \\ Utrecht University, Sorbonnelaan 16, 3584 CA Utrecht, The Netherlands, and Department of Preparative Organic Chemistry,
} Utrecht University, Padualaan 8, $3584 \mathrm{CH}$ Utrecht, The Netherlands

Received April 3, 1995; Revised Manuscript Received June 2, $1995^{\otimes}$

\begin{abstract}
Triple bond analogues of polyunsaturated fatty acids irreversibly inactivate lipoxygenases. During the inactivation the inhibitors are converted enzymatically [Kühn, H., et al. (1984) Eur. J. Biochem. 139, 577-583]. Since the converted inhibitor molecules may hold important information about the inactivation mechanism, we have determined the structure of the product that is formed during the irreversible inactivation of soybean lipoxygenase-1 by octadeca-9,12-diynoic acid (ODYA), the triple bond analogue of linoleic acid. This product is formed only in the presence of Fe(III)-lipoxygenase-1 and $\mathrm{O}_{2}$. It was purified by $\mathrm{C} 18$ solid phase extraction and reversed phase HPLC and was identified with UV, IR, and NMR spectroscopic and mass spectrometric techniques as the novel lipoxygenase product, 11-oxooctadeca-9,12-diynoic acid (11-oxo-ODYA). It is estimated that each lipoxygenase molecule produces 8-10 11-oxo-ODYA molecules before it is inactivated. Furthermore, we have shown that in a secondary reaction 3-4 molecules of 11-oxo-ODYA are covalently attached per lipoxygenase molecule, most likely, to solvent-exposed amino groups. This leads to the formation of a $\mathrm{N}$-penten-4-yn-3-one chromophore, $\mathrm{RC}(\mathrm{NHX})=\mathrm{CHC}(\mathrm{O}) \mathrm{C} \equiv \mathrm{CR}^{1}$, in which $\mathrm{X}$ stands for the protein and $\mathrm{R}$ or $\mathrm{R}^{1}$ for $\mathrm{CH}_{3}\left(\mathrm{CH}_{2}\right)_{4^{-}}$ or $-\left(\mathrm{CH}_{2}\right)_{7} \mathrm{COOH}$, respectively. $\mathrm{Fe}(\mathrm{II})-$ and $\mathrm{Fe}(\mathrm{III})$-lipoxygenase remain active upon reaction with purified 11-oxo-ODYA. It is concluded that (a) several enzymatic turnovers are required for the complete inactivation of lipoxygenase by ODYA and (b) covalent attachment of 11-oxo-ODYA occurs outside the active site and is not the cause of the inactivation.
\end{abstract}

Lipoxygenases (linoleate:oxygen oxidoreductase, EC 1.13.11.12) are iron-containing dioxygenases that convert unsaturated fatty acids possessing one or more $1 Z, 4 Z$ pentadiene systems into $Z, E$ conjugated hydroperoxy fatty acids. Mammalian lipoxygenases catalyze the first step in the formation of leukotrienes and lipoxins from arachidonic acid (Yamamoto, 1992). These products play an important role in the immune response and in inflammatory processes. The physiological role of plant lipoxygenases is less clear, but possible roles have been suggested in plant growth and development, biosynthesis of regulatory molecules, senescence, and response to wounding and pathogens (Siedow, 1991). Because of their abundance, plant lipoxygenases, and in particular lipoxygenase-1 from soybeans, are easily obtained in quantities that allow extensive structural (e.g., (Shibata et al., 1988; Van der Heijdt et al., 1992; Boyington et al., 1993; Minor, 1993) and mechanistic studies (e.g., de Groot et al., 1973; Verhagen et al., 1978; Ludwig et al., 1987; Schilstra et al., 1993). Because of structural and functional similarities between lipoxygenases from various sources, soybean lipoxygenase- 1 can serve in many respects as a model system for other lipoxygenases.

\footnotetext{
* To whom correspondence should be addressed.

₹ Bijvoet Center for Biomolecular Research, Department of BioOrganic Chemistry, Utrecht University.

Bijvoet Center for Biomolecular Research, Department of Biomolecular Mass Spectrometry, Utrecht University.

"Department of Preparative Organic Chemistry, Utrecht University.

Q Abstract published in Advance ACS Abstracts, July 15, 1995.
}

There is considerable interest in food chemistry and in medicine (Nuhn et al., 1991; Ford-Hutchinson et al., 1994) in compounds that specifically inhibit lipoxygenase catalysis, either reversibly or irreversibly. Analogues of natural fatty acids which contain one or more triple bonds instead of the $Z$-double bonds are well-known inhibitors of lipoxygenase and cyclooxygenase (Schewe et al., 1986). They cause irreversible inactivation of lipoxygenases. The inactivation mechanism and the inactivation potential of a number of these compounds have been investigated by several authors (Blain \& Shearer, 1965; Downing et al., 1970, 1972; Hammerström 1977; Corey \& Munroe, 1982; Corey \& Park, 1982; Kühn et al., 1984, 1991; Shieh et al., 1985; Corey, 1987; Borel et al., 1993). The mechanism by which triple bond analogues of natural substrates inactivate lipoxygenases has not yet been unambiguously established. However, it is generally accepted that the inactivation is caused by an $\mathrm{O}_{2}$-dependent, suicide-like action of the enzyme in which the inhibitor is enzymatically converted. In a study on the action of ${ }^{14} \mathrm{C}$-labeled ETYA ${ }^{1}$ methyl ester on soybean lipoxygenase, quite large amounts of a radioactively labeled product were observed (Kühn et al., 1984). The reaction product was not characterized any further, nor was the product formation quantified.

In order to identify the processes that eventually result in the irreversible inactivation, we studied the enzymatic conversion of the linoleic acid analogue octadeca-9,12diynoic acid (ODYA) by soybean lipoxygenase-1. In this 
paper, we present the characterization of the product that is formed during the irreversible inactivation of soybean $\mathrm{Fe}$ (III)-lipoxygenase-1 by ODYA.

\section{MATERIALS AND METHODS}

Materials. ODYA (octadeca-9,12-diynoic acid) was synthesized as described (Otsuki et al., 1986); tetradeca-5,8diyn-7-ol was prepared as described (Brandsma, 1988) and oxidized with $\mathrm{MnO}_{2}$ to tetradeca-5,8-diyn-7-one (Dinwoodie et al., 1962). A 1:1 mixture of 5-( $N$-methylamino)tetradeca5-en-8-yn-7-one and 6-( $N$-methylamino)tetradeca-6-en-9-yn8-one was prepared from tetradeca-5,8-diyn-7-one and methylamine as described (Metler et al., 1968).

Linoleic acid, $(9 Z, 12 Z)$-octadeca-9,12-dienoic acid (99\% pure), was from Sigma. 13-HPOD (13(S)-hydroperoxy-(9Z,$12 E$ )-octadeca-9,12-dienoic acid) was prepared enzymatically as described (Schilstra et al., 1992). Solutions of 13-HPOD $(200 \mathrm{mM})$, linoleic acid $(300 \mathrm{mM})$, and ODYA $(300 \mathrm{mM})$ were stored under nitrogen in methanol (Merck, gradient grade) until use. Acetic acid and sodiumborohydride were from Merck. Pyridine, hexamethyldisilazane, and trimethylchlorosilazane were from Fluka. All reagents were of the purest grade available. Lipoxygenase-1 from soybeans (White Hilum) was purified as described (Finazzi Agrò $e t$ al., 1973). Its concentration was estimated from the absorbance at $280 \mathrm{~nm}\left(\epsilon_{280}=1.6 \times 10^{5} \mathrm{~mol}^{-1} \cdot \mathrm{L} \cdot \mathrm{cm}^{-1}\right)$. The enzyme ( $\mathrm{Fe}(\mathrm{II})-$ lipoxygenase) was stored at $4{ }^{\circ} \mathrm{C}$ at a concentration of $17 \mathrm{mg} / \mathrm{mL}$ in $0.05 \mathrm{M}$ sodium acetate buffer, pH 5.5. Fe(III)-lipoxygenase was prepared by incubation of $\mathrm{Fe}(\mathrm{II})$-lipoxygenase with a 5-fold excess of 13-HPOD for approximately $3 \mathrm{~min}$, followed by dialysis against a 0.1 $\mathrm{M}$ sodium borate buffer, $\mathrm{pH} 10$ at $4{ }^{\circ} \mathrm{C}$. In all experiments $\mathrm{Fe}(\mathrm{III})-$ lipoxygenase was used immediately after preparation.

Equipment. UV absorption spectra were recorded with a Hewlett Packard HP 8452A diode array spectrophotometer. IR spectra of the compounds were recorded with a Mattson RS 5 FT-IR spectrometer equipped with a DTGS detector, using a HATR accessory with a $45^{\circ} \mathrm{ZnSe}$ crystal (SpecAc). Infrared spectra of all samples were measured from 4000 to $600 \mathrm{~cm}^{-1}$ with a resolution of $2 \mathrm{~cm}^{-1}$ and coaddition of 200 scans in a nitrogen atmosphere at $20^{\circ} \mathrm{C}$. Interferograms were apodized with a triangular function.

${ }^{1} \mathrm{H}-\mathrm{NMR}$ spectra were recorded with a Bruker AC 300 (300 $\mathrm{MHz}$ ) spectrometer in $\mathrm{CDCl}_{3}$ at $27{ }^{\circ} \mathrm{C}$. ${ }^{1} \mathrm{H}$ NMR chemical shifts are given in ppm $(\delta)$ relative to internal TMS.

EPR spectra of native lipoxygenase $(20 \mathrm{mg} / \mathrm{mL})$ were recorded with a Varian E-9 spectrometer at $5 \mathrm{~K}$.

GC-MS analysis was performed on an Interscience GC 800 Series gas chromatograph, equipped with a DB-1 column ( $30 \mathrm{~m} \times 0.31 \mathrm{~mm}$ i.d.) using a temperature gradient from $140{ }^{\circ} \mathrm{C}$, rising at $4{ }^{\circ} \mathrm{C} / \mathrm{min}$ to $300^{\circ} \mathrm{C}(2 \mathrm{~min})$. The mass

\footnotetext{
${ }^{1}$ Abbreviations: ETYA, eicosa-5,8,11,14-tetraynoic acid; EPR, electron paramagnetic resonance; FAB-MS, fast atom bombardment mass spectrometry; FAB-MS/MS, FAB ionization, collision induced decompositions (CID) in the third field-free region (3rd FFR); FT-IR, Fourier transform infrared spectroscopy; GC-MS, gas chromatographymass spectrometry; (RP-)HPLC, (reversed phase) high performance liquid chromatography; 13-HPOD, $13(S)$-hydroperoxy- $(9 Z, 11 E)$-octadeca-9,12-dienoic acid; 11-hydroxy-ODYA, 11-hydroxyoctadeca-9, 12-diynoic acid; 11-oxo-ODYA, 11-oxooctadeca-9,12-diynoic acid; ' $\mathrm{H}$ NMR, proton nuclear magnetic resonance; ODYA, octadeca-9,12diynoic acid; TMS, tetramethylsilane.
}

spectra were recorded with a Fisons Instruments MD 800 MassLab spectrometer under electron impact with an ionization energy of $70 \mathrm{eV}$.

FAB-MS analyses were carried out on a JEOL JMS SX/ SX $102 \mathrm{~A}$ four-sector mass spectrometer, operated at $10 \mathrm{kV}$ accelerating voltage, equipped with a JEOL MS-FAB $10 \mathrm{D}$ FAB gun operated at a $10 \mathrm{~mA}$ emission current, producing a beam of $6 \mathrm{keV}$ xenon atoms. Data acquisition and processing were performed using JEOL Complement software. MS/MS CID mass spectra were acquired using a collision cell in the third field-free region of the instrument, using air as collision gas. The pressure of the collision gas was adjusted to obtain a $50 \%$ reduction of the beam. Resolution of the instrument was maintained at 1000 throughout all experiments. The underivatized samples were dissolved in $\mathrm{CHCl}_{3}$ and a $m$-nitrobenzyl alcohol/sodium iodide matrix was used.

Oxygen uptake was measured in $1 \mathrm{~mL}$ of $0.1 \mathrm{M}$ sodium borate buffer, $\mathrm{pH} 10.0$ at $25^{\circ} \mathrm{C}$, using a standard Hansatech Clarke-type electrode disk and a Hansatech CB1 control box.

Lipoxygenase activity measurements were carried out using a Hi-Tech SF-51 stopped-flow apparatus equipped with an LS-10 light source and PM-60 photomultiplier.

HPLC analyses were performed using a Hewlett Packard HP 1090 liquid chromatograph, equipped with an HP 1040A diode array detector and an HP 79994A analytical workstation. HPLC analyses and purification of fatty acids were carried out on CP-Spher C18 $(5 \mu \mathrm{m} ; 250 \times 4.6 \mathrm{~mm}$ i.d.; Chrompack) or Cosmosil 5C18-AR (5 $\mu \mathrm{m} ; 250 \times 10 \mathrm{~mm}$ i.d.; Nacalai Tesque) columns, using a methanol/water/acetic acid mixture $(80 / 20 / 0.01 \mathrm{v} / \mathrm{v})$ as the eluent at flow rates of $1 \mathrm{~mL} / \mathrm{min}$ (Chrompack column) or $3 \mathrm{~mL} / \mathrm{min}$ (Nacalai Tesque column). Sephadex G-25 $(25 \mathrm{~cm} \times 1 \mathrm{~cm}$ i.d.; Pharmacia; Gilson Minipuls 3 pump, elution rate $0.5 \mathrm{~mL} /$ min) or Supradex G-200 (100 cm $\times 25$ mm i.d.; Pharmacia; Pharmacia FPLC P-500 pump and Liquid Chromatography Controller LCC-500, elution rate $0.4 \mathrm{~mL} / \mathrm{min}$ ) columns were used for size exclusion chromatography. The eluates were passed through a flow cell $(300 \mu \mathrm{L})$, and every $5 \mathrm{~s}$ spectra were recorded.

Preparation and Purification of the Reaction Products. In order to obtain sufficient amounts of reaction product, typically $2 \mu \mathrm{M}$ Fe(III)-lipoxygenase was incubated for 90 min at $25{ }^{\circ} \mathrm{C}$ in air-saturated $0.1 \mathrm{M}$ sodium borate buffer, $\mathrm{pH} 10.0$, with 50 or $75 \mu \mathrm{M}$ ODYA in a total volume of 100 $\mathrm{mL}$. The reaction was terminated by acidifying the mixture to $\mathrm{pH} 5$ with $3 \mathrm{M} \mathrm{HCl}$ and then the fatty acids were extracted as described (Van Aarle et al., 1991). Further purification was carried out by preparative HPLC (Nacalai Tesque column, see Equipment section). The pure compound was dissolved in $250 \mu \mathrm{L}$ of methanol and stored under nitrogen at $-25{ }^{\circ} \mathrm{C}$.

Chemical Modifications. After purification, the enzymatically converted ODYA was reduced, methylated, hydrogenated, and silylated as described (Van Aarle et al., 1991).

\section{RESULTS}

To study the mechanism of inactivation of lipoxygenase by triple bond analogues of natural fatty acid substrates, $\mathrm{Fe}$ (III) - and $\mathrm{Fe}$ (II)-lipoxygenases were incubated with the linoleic acid analogue octadeca-9,12-diynoic acid (ODYA), and the reaction products were analyzed. 


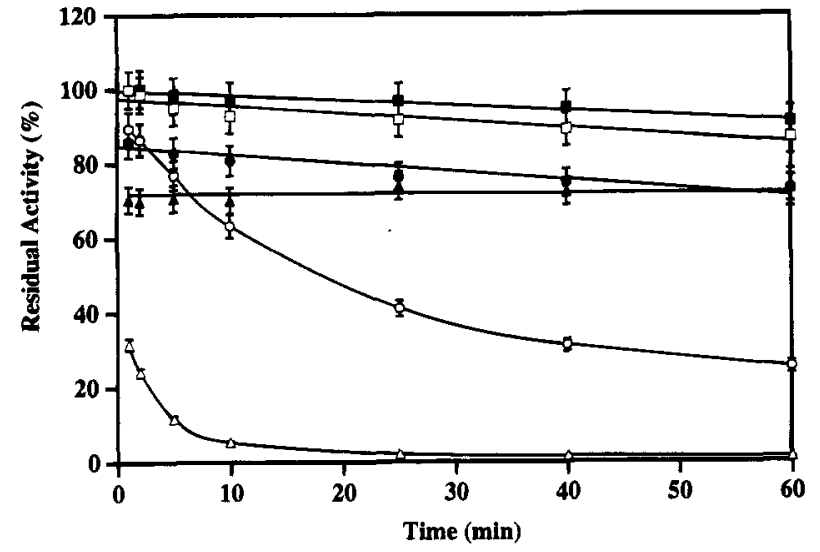

FIGURE 1: Residual activities, measured in a stopped-flow apparatus, of $100 \mathrm{nM} \mathrm{Fe}(\mathrm{II})$ - (closed symbols) and $\mathrm{Fe}$ (III)-soybean lipoxygenase-1 (open symbols) after treatment with 0 (squares), 2 (circles), or $20 \mu \mathrm{M}$ ODYA (triangles) in $0.1 \mathrm{M}$ sodium borate buffer, $\mathrm{pH} 10.0$ at $25^{\circ} \mathrm{C}$. The reactions were initiated by the addition of ODYA at $t=0$.

Inactivation of $\mathrm{Fe}(I I I)-$ and $\mathrm{Fe}(I I)$-Lipoxygenase by ODYA. In order to investigate whether the effect of ODYA on $\mathrm{Fe}(\mathrm{III})$-lipoxygenase is different from that on $\mathrm{Fe}$ (II)lipoxygenase, 2 or $20 \mu \mathrm{M}$ ODYA was added (at $t=0$ ) to $100 \mathrm{nM}$ solutions of either Fe(III)-lipoxygenase or, native, $\mathrm{Fe}(\mathrm{II})$-lipoxygenase in $0.1 \mathrm{M}$ sodium borate buffer, $\mathrm{pH} 10.0$. The residual activities were measured in a stopped-flow apparatus by mixing the enzyme solutions with equal volumes of $100 \mu \mathrm{M}$ linoleic acid in $0.1 \mathrm{M}$ sodium borate buffer, $\mathrm{pH}$ 10.0. The fraction of active enzyme was calculated from the rate of 13-HPOD formation in the test solution (Schilstra et al., 1992). All reactions were carried out at $25^{\circ} \mathrm{C}$. The results are shown in Figure 1. The activities are expressed as percentages of the 13-HPOD formation rate observed in the absence of ODYA (absolute value: $9.1 \mu \mathrm{M} / \mathrm{s} ; 10 \%$ decrease in activity over $1 \mathrm{~h}$ of incubation at $25^{\circ} \mathrm{C}$ ). Over a $1 \mathrm{~h}$ period of incubation, the enzymatic activity decreased by approximately $25 \%$ when 2 or $20 \mu \mathrm{M}$ ODYA was added to $\mathrm{Fe}(\mathrm{II})$-lipoxygenase, but by $70 \%$ ( $2 \mu \mathrm{M}$ ODYA) or $99 \%$ ( $20 \mu \mathrm{M}$ ODYA) when Fe(III)-lipoxygenase was used. The duration of the lag phase in the incubation mixtures containing $\mathrm{Fe}(\mathrm{II})$-lipoxygenase increased from $0.4 \mathrm{~s}$ (in the absence of ODYA) to $1.2 \mathrm{~s} \mathrm{(2}$ or $20 \mu \mathrm{M}$ ODYA). From this experiment it can be concluded that ODYA is able to inactivate Fe(III)-lipoxygenase, but has no effect on the activity of $\mathrm{Fe}$ (II)-lipoxygenase. The small decrease in enzyme activity in the $\mathrm{Fe}$ (II)-lipoxygenase samples may be explained by the presence of some Fe(III)lipoxygenase in the $\mathrm{Fe}(\mathrm{II})$-lipoxygenase preparation. The EPR spectrum of a concentrated native enzyme preparation indicated the presence of some Fe(III)-lipoxygenase (data not shown). The increase of the lag phase of the, native, $\mathrm{Fe}(\mathrm{II})$-lipoxygenase preparations after addition of ODYA also points to the presence of some $\mathrm{Fe}(\mathrm{III})$-lipoxygenase (see Discussion) (Schilstra et al., 1994).

Spectral Changes during the Reaction of ODYA with Lipoxygenase. Spectral changes or reaction products were not detected when $100 \mathrm{nM}$ Fe(II)-lipoxygenase was incubated with ODYA for periods up to $5 \mathrm{~h}$. However, after mixing ODYA with $\mathrm{Fe}(\mathrm{III})$-lipoxygenase, chromophores with absorbance maxima at 258 and $340 \mathrm{~nm}$ are formed. The higher the concentration of Fe(III)-lipoxygenase at the start of the reaction, the more of these chromophores are

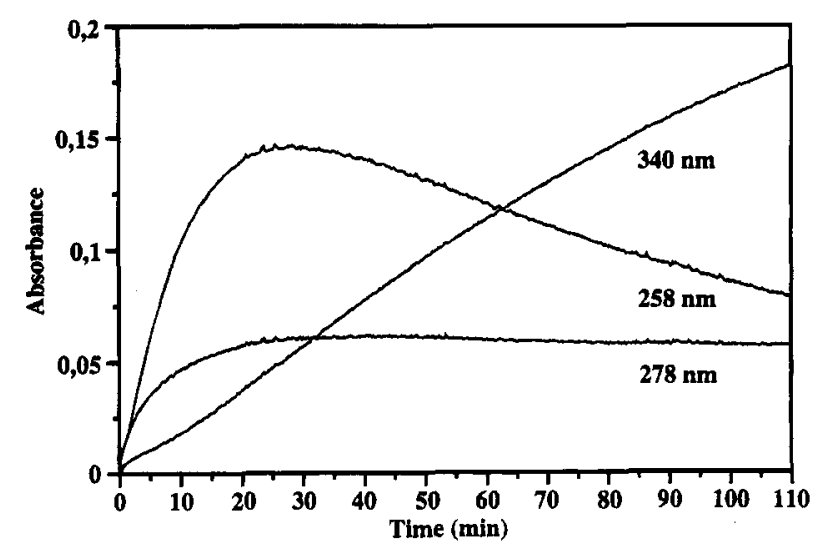

FIGURE 2: Time dependence of the absorbance at 258,278 , and $340 \mathrm{~nm}$ of the reaction between $2 \mu \mathrm{M} \mathrm{Fe}$ (III)-lipoxygenase and $75 \mu \mathrm{M}$ ODYA in $0.1 \mathrm{M}$ sodium borate buffer, $\mathrm{pH} 10.0$. The values were corrected for the values of $A_{258}, A_{278}$, and $A_{340}$ of a $2 \mu \mathrm{M}$ $\mathrm{Fe}(\mathrm{III})$-lipoxygenase solution.

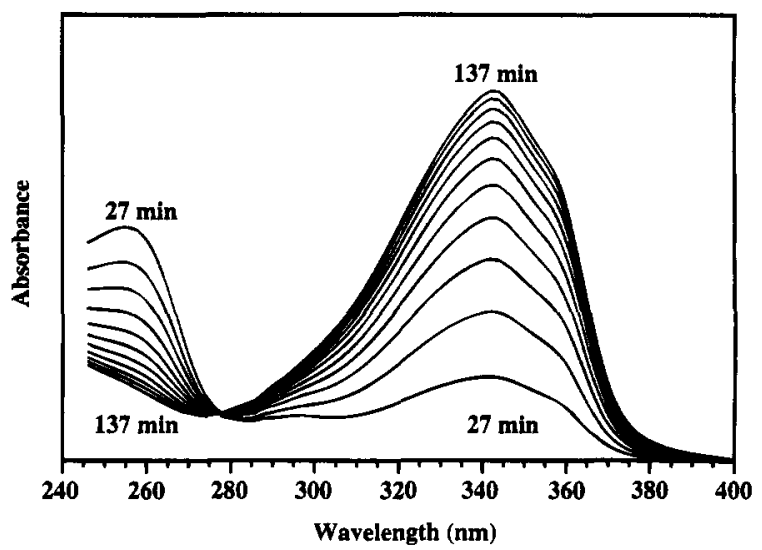

FIGURE 3: Spectra, corrected for the protein absorbance, of the reaction between $2 \mu \mathrm{M}$ Fe(III)-lipoxygenase and $75 \mu \mathrm{M}$ ODYA in $0.1 \mathrm{M}$ sodium borate buffer, $\mathrm{pH} 10.0$, recorded every $10 \mathrm{~min}$ during the late stages of the reaction (where $A_{278}$ was constant). Absorption below $240 \mathrm{~nm}$ is not shown because of protein interference.

formed. Neither of the chromophores is formed under anaerobic conditions or after incubation of ODYA with heatinactivated $\mathrm{Fe}$ (III)-lipoxygenase.

In Figure 2, the time course of a typical reaction between $\mathrm{Fe}(\mathrm{III})-$ lipoxygenase $(2 \mu \mathrm{M})$ and ODYA $(75 \mu \mathrm{M})$ is shown. In Figure 3 the spectra (corrected for the protein absorbance) of the reaction mixture at $10 \mathrm{~min}$ intervals, starting at $t=$ 27 min, are shown. In Figures 2 and 3 the isosbestic point is present at $278 \pm 2 \mathrm{~nm}$ from $27 \mathrm{~min}$ after the start of the reaction onward. The data indicate that the chromophore at $258 \mathrm{~nm}$ is formed in a primary reaction and that it is converted into the chromophore at $340 \mathrm{~nm}$ in a secondary reaction. The primary reaction stops when the dioxygenase activity has ceased, but the secondary reaction continues. Since the $340 \mathrm{~nm}$ chromophore is formed in the secondary reaction at the expense of the chromophore at $258 \mathrm{~nm}$, the ratio of the molar absorption coefficients $\left(Q=\epsilon_{258} / \epsilon_{340}\right)$ can be calculated as follows: $Q=-\Delta A_{258} / \Delta A_{340} . \Delta A$ is the absorbance change measured over $15 \mathrm{~min}$ since this period of time afforded a sufficient signal to noise ratio. In Figure 4 it is shown that $Q$ remains constant $(0.58 \pm 0.02)$ from approximately $30 \mathrm{~min}$ after the start of the reaction. The value of the absorbance that would have been observed at $258 \mathrm{~nm}$ if there had been no conversion into the chromophore 


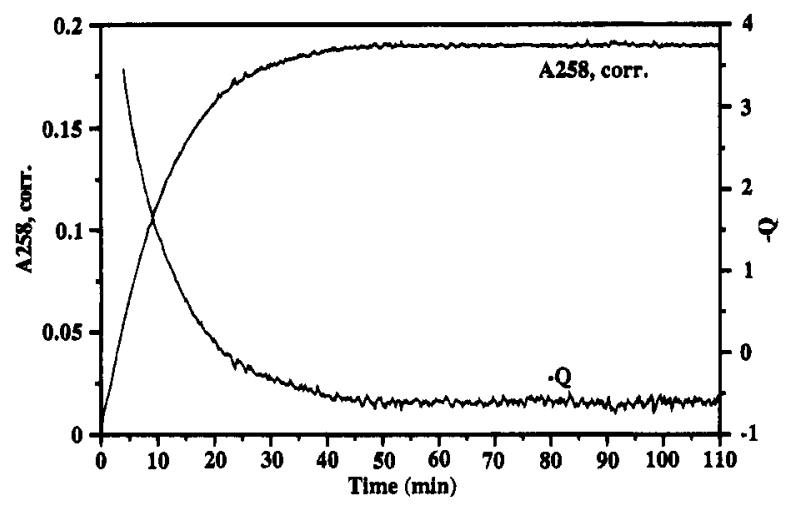

FIGURE 4: Time course of $Q$ and $A_{258}{ }^{\text {corr }}$ in the reaction between 2 $\mu \mathrm{M} \mathrm{Fe}$ (III)-lipoxygenase and $75 \mu \mathrm{M}$ ODYA in $0.1 \mathrm{M}$ sodium borate buffer, $\mathrm{pH}$ 10.0. Curve 1 (right vertical axis): values of $Q$, calculated at time $=t(\mathrm{~min})$ as $Q=\left(A_{258, t}-A_{258, t+15}\right) /\left(A_{340, t}\right.$ $A_{340, t+15}$ ). Curve 2 (left vertical axis): values of $A_{258^{\text {corr }}}$, calculated from $A_{258}$ and $A_{340}$ in Figure 2 as $A_{258}{ }^{\text {corr }}=A_{258}+0.58 A_{340}$.

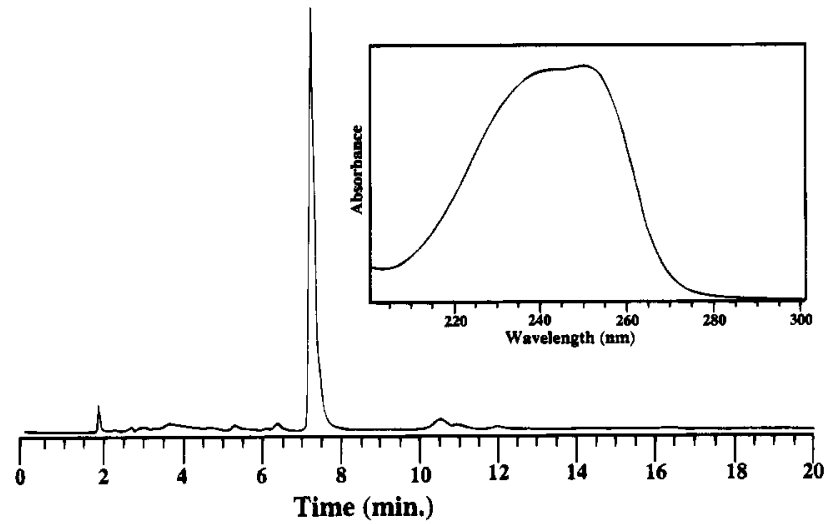

FIGURE 5: HPLC chromatogram $(\lambda=242 \mathrm{~nm})$ and UV spectrum (inset) of the product formed by the reaction of $\mathrm{Fe}(\mathrm{III})$-soybean lipoxygenase- 1 with ODYA.

at $340 \mathrm{~nm}\left(A_{258}{ }^{\mathrm{corr}}=A_{258}+0.58 A_{340}\right)$ is also indicated in Figure 4.

During the conversion of ODYA by Fe(III)-lipoxygenase, $\mathrm{O}_{2}$ is consumed. $A_{258}{ }^{\text {corr }}$, after the primary reaction had stopped, and the total $\mathrm{O}_{2}$ uptake in the reaction between 2 $\mu \mathrm{M} \mathrm{Fe}(\mathrm{III})$-lipoxygenase and varying amounts of ODYA $(6,15,30$, and $60 \mu \mathrm{M}, 0.3,0.6$, and $1.2 \mathrm{mM})$ were measured. The relationship between the total $\mathrm{O}_{2}$ uptake and $A_{258}{ }^{\text {corr }}$ was linear, with an intercept of $0.01 \pm 0.02 \mathrm{~cm}^{-1}$ and a slope of $(1.0 \pm 0.1) \times 10^{4} \mathrm{~mol}^{-1} \cdot \mathrm{L} \cdot \mathrm{cm}^{-1}$. The linear correlation coefficient was 0.97. Assuming that one molecule of $\mathrm{O}_{2}$ is consumed in the formation of one $258 \mathrm{~nm}$ chromophore (hereafter referred to as P1), $\epsilon_{258}$, the molar absorption coefficient of $\mathrm{P} 1$ at $258 \mathrm{~nm}$, is equal to the slope of the line. Using this $\epsilon_{258}$, it was calculated that 8-10 P1 chromophores per lipoxygenase molecule were formed during inactivation. The chromophore at $340 \mathrm{~nm}$ will be referred to as P2.

Isolation of $P 1$. P1 could be isolated via $\mathrm{C} 18$ solid phase extraction provided that the reaction was terminated before $\mathrm{P} 1$ was converted into the chromophore at $340 \mathrm{~nm}$ (P2). The extract was submitted to analytical and preparative RP-HPLC analysis. The HPLC elution pattern and UV spectrum are shown in Figure 5. No peaks with an absorption maximum at $340 \mathrm{~nm}$ were observed in this elution pattern.

$U V$ and FTIR Spectroscopy of P1. The UV absorption spectrum of purified $\mathrm{P} 1$ has maxima at 242 and $258 \mathrm{~nm}$ with relative intensities of 1.00:1.06 (see inset, Figure 5). The value of $\epsilon_{258}$ is estimated to be approximately $1.0 \times 10^{4}$ $\mathrm{mol}^{-1} \cdot \mathrm{L}^{\circ} \mathrm{cm}^{-1}$ (see above). This chromophore is absent in the spectrum of $\mathrm{NaBH}_{4}$-reduced P1. The UV spectrum of P1 strongly resembles that of tetradeca-5,8-diyn-7-one, which has absorption maxima at 240 and $250 \mathrm{~nm}$, with relative intensities of 1.02:1.00 and an $\epsilon_{250}$ of $1.17 \times 10^{4} \mathrm{~mol}^{-1} \cdot \mathrm{Lcm}^{-1}$ in methanol. Similar values were reported for trideca-5,8diyn-7-one, which has absorption maxima at 239.5 and 250 $\mathrm{nm}$, with relative intensities of 1.01:1.00 and an $\epsilon_{250}$ of 1.33 $\times 10^{4} \mathrm{~mol}^{-1} \cdot \mathrm{L}^{\circ} \mathrm{cm}^{-1}$, when measured in ethanol (Metler et al., 1968; Migliorese et al., 1974).

Strong absorptions at 1626 and $2208 \mathrm{~cm}^{-1}$ in the IR spectrum of $P 1$ indicate the presence of a conjugated carbonyl group or a double bond and an asymmetrically substituted triple bond in the molecule. These IR absorptions correlate very well with those at $1624(\mathrm{C}=\mathrm{O})$ and $2205(\mathrm{C} \equiv \mathrm{C}) \mathrm{cm}^{-1}$ of tetradeca-5,8-diyn-7-one. The spectrum of $\mathrm{NaBH}_{4}$ reduced $\mathrm{P} 1$ shows absorptions at 3380 and $2222 \mathrm{~cm}^{-1}$, indicating the presence of a hydroxyl group and a triple bond, respectively. These values are in good agreement with those found at $3356(\mathrm{OH})$, and 2198,2222 , and $2254(\mathrm{C} \equiv \mathrm{C})$ for trideca-5,8-diyn-7-ol (Metler et al., 1968).

Signals characteristic for allenic bonds are completely absent in both the UV and IR spectra. The disappearance of the absorptions at 242 and $258 \mathrm{~nm}$ (UV) and at $1626 \mathrm{~cm}^{-1}$ (IR) and the appearance of a signal at $3380 \mathrm{~cm}^{-1}$ (IR) upon reduction with $\mathrm{NaBH}_{4}$ provide strong evidence for the presence of a carbonyl group in P1.

Mass Spectrometry of P1. FAB-MS in the negative mode was used to determine the molecular mass of underivatized fatty acids because exclusively $[\mathrm{M}-\mathrm{H}]^{-}$ions are formed without appreciable fragmentation taking place (Tomer $e t$ al., 1983; Jensen et al., 1985). The FAB spectrum of ODYA shows a $[\mathrm{M}-\mathrm{H}]^{-}$ion at $m / z 275$, while $F A B$ analysis of P1 shows a $[\mathrm{M}-\mathrm{H}]^{-}$ion at $m / z 289$. The FAB spectrum of $\mathrm{NaBH}_{4}$-reduced P1 contains a $[\mathrm{M}-\mathrm{H}]^{-}$ion at $\mathrm{m} / 2291$. The increase in molecular mass from 276 (ODYA) to 290 (P1) and from 290 to $292\left(\mathrm{NaBH}_{4}\right.$-reduced P1) points to the presence of a carbonyl group in $\mathrm{P} 1$ and the conversion into a hydroxyl group in $\mathrm{NaBH}_{4}$-reduced $\mathrm{P} 1$ (see above). This was confirmed by the elimination of $\mathrm{H}_{2} \mathrm{O}(\mathrm{m} / \mathrm{z} 319)$ from the molecular ion at $\mathrm{m} / \mathrm{z} 337$ in the FAB-MS/MS CID spectrum of $\mathrm{NaBH}_{4}$-reduced P1 (see Figure 6).

Determination of the positions of unsaturated bonds in fatty acids was achieved by following the collision induced decomposition (CID) in the third field-free region (3rd FFR) of alkali metal cationized ions (Adams \& Gross, 1987). The best results were obtained with sodium cationized ions [M $+2 \mathrm{Na}-\mathrm{H}]^{+}$. In these FAB-MS/MS CID measurements, remote-charge site fragmentations, interrupted by unsaturated bonds, take place. In the spectra (see Figure 6) of ODYA, $\mathrm{P} 1$, and $\mathrm{NaBH}_{4}$-reduced $\mathrm{P} 1$, the ions at $m / z$ 90, 104, 117 , 131 , and 173 corresponding to $\left[\mathrm{CO}_{2} \mathrm{Na}_{2}\right]^{\circ+},\left[\mathrm{C}_{2} \mathrm{H}_{2} \mathrm{O}_{2} \mathrm{Na}_{2}\right]^{\circ+}$, $\left[\mathrm{C}_{3} \mathrm{H}_{3} \mathrm{O}_{2} \mathrm{Na}_{2}\right]^{+},\left[\mathrm{C}_{4} \mathrm{H}_{5} \mathrm{O}_{2} \mathrm{Na}_{2}\right]^{+}$, and $\left[\mathrm{C}_{7} \mathrm{H}_{11} \mathrm{O}_{2} \mathrm{Na}_{2}\right]^{+}$, respectively, prove that the part of the molecule adjoining the carboxyl group has not changed and that the triple bond between $\mathrm{C} 9$ and $\mathrm{C} 10$ is unaffected in $\mathrm{P} 1$ and in $\mathrm{NaBH}_{4}$ reduced $\mathrm{P} 1$. In the high mass regions in the spectra of all three compounds (ODYA, $\mathrm{P} 1$, and $\mathrm{NaBH}_{4}$-reduced $\mathrm{P} 1$ ) the fragments $\left[\mathrm{M}-\mathrm{CH}_{4}\right]^{+}(\mathrm{m} / \mathrm{z} 305,319$, and 321), [M $\left.\mathrm{C}_{2} \mathrm{H}_{6}\right]^{+}\left(\mathrm{m} / \mathrm{z} 291,305 \text {, and 307), [M - } \mathrm{C}_{3} \mathrm{H}_{8}\right]^{+}(\mathrm{m} / z 277,291$, and 293), and $\left[\mathrm{M}-\mathrm{C}_{4} \mathrm{H}_{9}\right]^{++}(\mathrm{m} / 2264,278$, and 280) are observed. These fragmentations indicate that the conversion 
$\mathbf{A}$

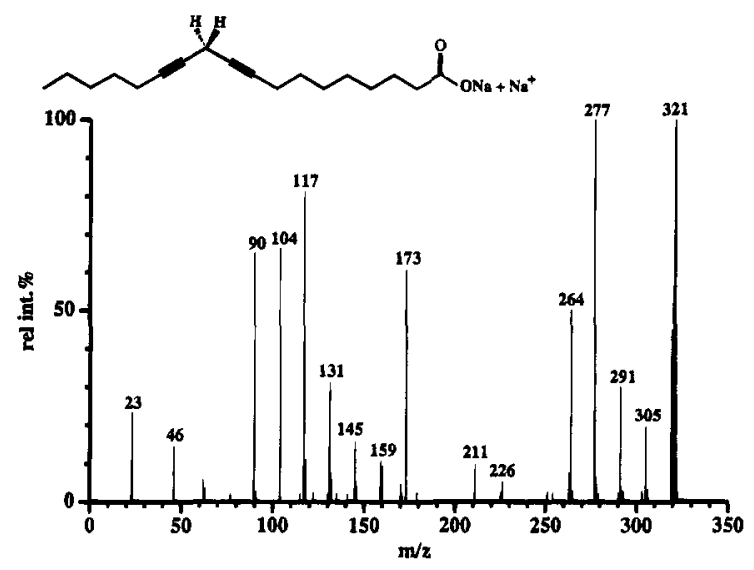

B

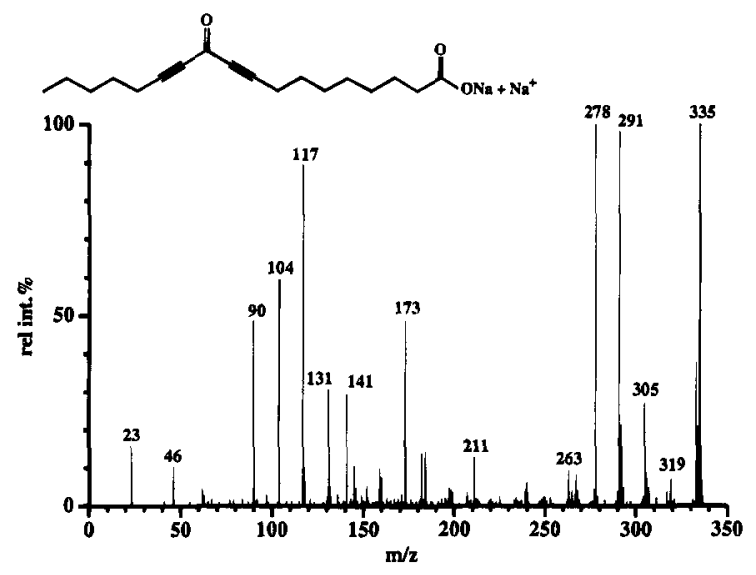

$\mathbf{C}$

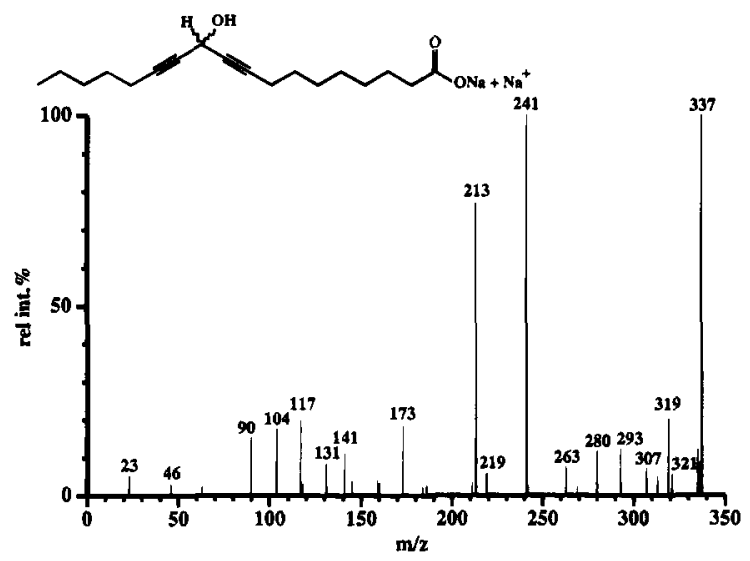

FIGURE 6: FAB-MS/MS spectra of the disodium salts of ODYA (A), 11-oxo-ODYA (B) and 11-hydroxy-ODYA (C).

of ODYA into $\mathrm{P} 1$ and the subsequent $\mathrm{NaBH}_{4}$ reduction of $P 1$ did not change the methyl end of the molecule and that the triple bond between $\mathrm{C} 12$ and $\mathrm{C} 13$ is unaltered. The FABMS/MS CID data of $\mathrm{NaBH}_{4}$-reduced P1 also show, apart from the ions described above, major ions at $\mathrm{m} / \mathrm{z} 213$ and 241 which are assigned to $\left[\mathrm{HC} \equiv \mathrm{C}\left(\mathrm{CH}_{2}\right)_{7} \mathrm{COONa}_{2}\right]^{+}$and
$\left[\mathrm{H}(\mathrm{C}=\mathrm{O}) \mathrm{C} \equiv \mathrm{C}\left(\mathrm{CH}_{2}\right)_{7} \mathrm{COONa}_{2}\right]^{+}$, respectively. These fragments are formed via a $\mathrm{H}$-shift and are formed only when the hydroxyl is located at $\mathrm{C} 11$ in $\mathrm{NaBH}_{4}$-reduced $\mathrm{P} 1$. On the basis of the FAB and FAB-MS/MS CID spectra of ODYA, $\mathrm{P} 1$, and $\mathrm{NaBH}_{4}$-reduced $\mathrm{P} 1$, it can be concluded that the C11 methylene group of ODYA has been oxidized to a carbonyl group.

The GC-MS (EI ionization) mass spectrum of fully reduced, methylated, and silylated $\mathrm{P} 1$ contains major ions at $\mathrm{m} / \mathrm{z} 201$ and 287 which are assigned to $\left[\mathrm{CH}_{3}\left(\mathrm{CH}_{2}\right)_{6}\right.$ $(\mathrm{OTMS}) \mathrm{CH}]^{+}$and $\left[\mathrm{CH}(\mathrm{OTMS})\left(\mathrm{CH}_{2}\right)_{9} \mathrm{COOCH}_{3}\right]^{+}$, respectively, providing further evidence that the carbonyl group of $\mathrm{P} 1$ is located at $\mathrm{C} 11$.

NMR Spectroscopy of $P 1$. Purified P1 was also characterized using ${ }^{1} \mathrm{H}-\mathrm{NMR}$ spectroscopy. Comparison of the spectra of ODYA and P1 (Table 1) reveals that the two protons of the 1,4-diyn system (3.12 ppm, H-11) in the spectrum of ODYA do not occur in the spectrum of P1. Furthermore, the small couplings of $2.4 \mathrm{~Hz}$ of $\mathrm{H}-11$ with $\mathrm{H}-8$ and $\mathrm{H}-14$, present in the spectrum of ODYA, are absent in the spectrum of $\mathrm{P} 1$, proving that no protons in $\mathrm{P} 1$ separated by a triple bond are present. The protons $\mathrm{H}-8$ and $\mathrm{H}-14$ of $\mathrm{P} 1$ are chemically identical and have shifted downfield (2.39 ppm) relative to $\mathrm{H}-8$ and $\mathrm{H}-14$ of ODYA, showing the presence of an electronegative substituent near these protons.

The ${ }^{1} \mathrm{H}$-NMR spectrum of $\mathrm{NaBH}_{4}$-reduced $\mathrm{P} 1$ resembles that of ODYA. The resonances of the chemically identical protons $\mathrm{H}-8$ and $\mathrm{H}-14$ have shifted upfield $(2.22 \mathrm{ppm})$ compared with those in the spectrum of $\mathrm{P} 1$, and a small coupling of $2.0 \mathrm{~Hz}$, just like in the spectrum of ODYA, reappeared. A signal at $5.1 \mathrm{ppm}$ with a coupling of $1.9 \mathrm{~Hz}$ indicates the presence of a proton next to a triple bond close to an electronegative substituent. The fact that the protons $\mathrm{H}-8$ and $\mathrm{H}-14$ have a coupling with a proton at $5.1 \mathrm{ppm}$ after $\mathrm{NaBH}_{4}$ reduction proves that both $\mathrm{H}-8$ and $\mathrm{H}-14$ are situated next to a triple bond, and according to the results presented above, the carbonyl group can only be situated at $\mathrm{C} 11$, between the two triple bonds.

We conclude, therefore, that $P 1$ is 11-oxooctadeca-9,12diynoic acid (11-oxo-ODYA) and that $\mathrm{NaBH}_{4}$-reduced $\mathrm{P} 1$ is 11-hydroxyoctadeca-9,12-diynoic acid (11-hydroxyODYA).

Characterization of $P 2$. Attempts to extract $\mathrm{P} 2$ via $\mathrm{C} 18$ solid phase, ether, or Bligh \& Dyer extractions (Bligh \& Dyer, 1959) failed. The reason for this became clear when reaction mixtures were subjected to size exclusion chromatography. A mixture of $8 \mu \mathrm{M} \mathrm{Fe}$ (III)-lipoxygenase and 75 $\mu \mathrm{M}$ ODYA was allowed to react for $5 \mathrm{~h}$ at $25^{\circ} \mathrm{C}$. When the reaction was terminated, the absorbances at 258 and 340 $\mathrm{nm}$ were 0.17 and 0.55 , respectively, indicating that approximately $45 \mu \mathrm{M}$ ODYA was converted into 11-oxoODYA in the primary reaction and that almost $30 \mu \mathrm{M}(65 \%)$

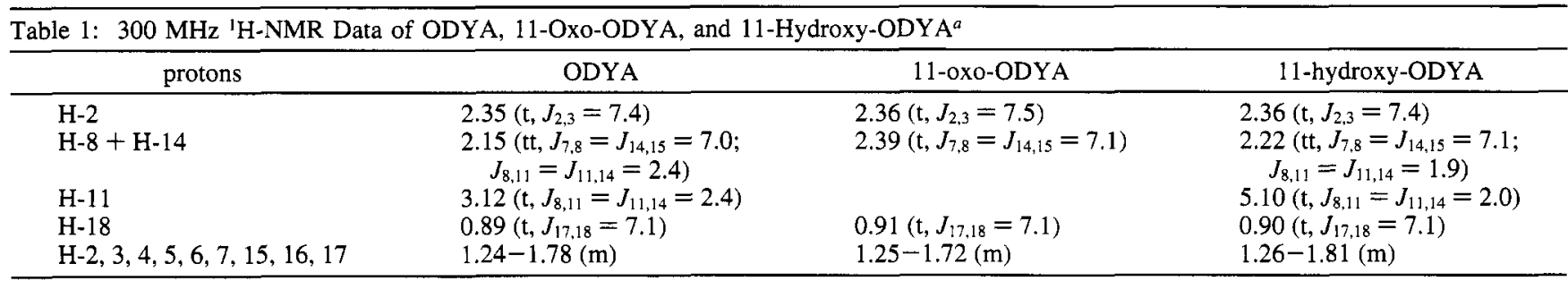

${ }^{a}$ Chemical shifts $(\delta)$ are given in ppm at $27^{\circ} \mathrm{C}$ and were measured in $\mathrm{CDCl}_{3}$ relative to internal TMS. Coupling constants (in parentheses) are given in $\mathrm{Hz} ; \mathrm{t}=$ triplet, $\mathrm{tt}=$ triple triplet, $\mathrm{m}=$ multiplet. 


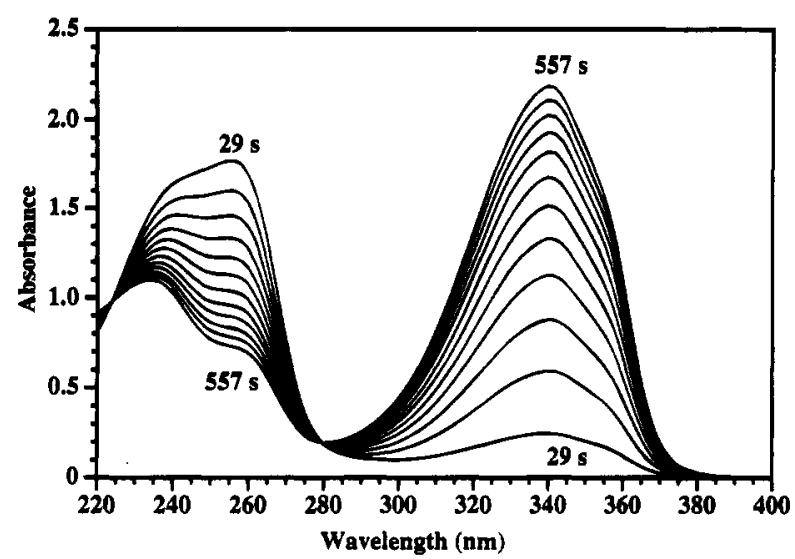

FIGURE 7: UV absorption spectra, recorded every $50 \mathrm{~s}$, during the reaction between $170 \mu \mathrm{M} 11$-oxo-ODYA $\left(P_{\mathrm{c} 258}, A_{258}=1.85\right)$ and $60 \mathrm{mM}$ methylamine in $0.1 \mathrm{M}$ sodium borate buffer, $\mathrm{pH} 10.0$.

11-oxo-ODYA was converted into P2 in the secondary reaction. When this mixture was passed over a Sephadex G-25 column, P2 coeluted with the high-molecular-mass fraction. An identical reaction mixture was also fractionated on a Supradex G-200 column. Also in this experiment, P2 coeluted with the protein peak. Therefore, it seems likely that P2 is formed when 11-oxo-ODYA binds covalently to the enzyme.

In agreement with this suggestion it is observed that incubation of 12.7 $\mu \mathrm{M}$ 11-oxo-ODYA for $3 \mathrm{~h}$ in $0.1 \mathrm{M}$ sodium borate buffer, $\mathrm{pH} 10.0$, does not result in any change in the UV absorption spectrum of 11-oxo-ODYA. However, when 11-oxo-ODYA is incubated with $2 \mu \mathrm{M} \mathrm{Fe}$ (III)- or $\mathrm{Fe}(\mathrm{II})$-lipoxygenase, the absorbance at $258 \mathrm{~nm}$ decreases in $3 \mathrm{~h}$ from 0.140 to 0.068 , indicating that $6.5 \mu \mathrm{M} 11$-oxoODYA is converted into P2. The absorbance at $340 \mathrm{~nm}$ increases from 0.015 to 0.142 . The spectra taken during the reaction exhibit an isosbestic point at approximately $278 \mathrm{~nm}$. The value of $Q\left(\epsilon_{258} / \epsilon_{340}\right)$, calculated from these data, is 0.57 \pm 0.2 . Both $\mathrm{Fe}(\mathrm{II})-$ and $\mathrm{Fe}(\mathrm{III})-$ lipoxygenases are fully active after treatment with 11-oxo-ODYA.

According to the experiments described above, each lipoxygenase molecule can covalently bind on average 3-4 molecules of 11-oxo-ODYA. This demonstrates, because of this stoichiometry, and in view of the fact that lipoxygenase remains fully active after treatment with purified 11 oxo-ODYA, that the covalent attachment of 11-oxo-ODYA does not take place in the active site of the enzyme. Compounds with a 1,4-pentadiyn-3-one or 1-propyn-3-one system react readily with primary amines (Chauvelier, 1954; Metler et al., 1968) to form a variety of products, including Schiff bases, addition products, pyridones, and pyrones, depending on the reaction conditions. It is possible that $\mathrm{P} 2$ is formed in a reaction between solvent-exposed primary amino groups of the enzyme and 11-oxo-ODYA. To obtain evidence for this suggestion, a large excess $(60 \mathrm{mM})$ of the primary amines methylamine or 3-amino-1-propanol was added to $170 \mu \mathrm{M}$ solutions of 11-oxo-ODYA $\left(A_{258}=1.85\right)$ in $0.1 \mathrm{M}$ sodium borate buffer, $\mathrm{pH} 10.0$. The course of the reaction of 11-oxo-ODYA and methylamine is shown in Figure 7. From the results it was calculated that $Q$ is 0.54 \pm 0.03 . The absorbance at $340 \mathrm{~nm}$ in the spectrum of $P 2$ has a shoulder at $360 \mathrm{~nm}$. The absorbance at $340 \mathrm{~nm}$ that emerges in the reaction between 11-oxo-ODYA and methylamine also has a shoulder at $360 \mathrm{~nm}$. The product of the reaction between 11-oxo-ODYA and methylamine was isolated via $\mathrm{C} 18$ solid phase extraction and gave two partially overlapping peaks with identical UV-spectra in RP-HPLC analysis. Satisfactory separation of the peaks was not achieved. The adducts were readily soluble in methanol and in chloroform and were stable under mild acidic conditions. FAB-MS analysis of the underivatized adduct mixture revealed only one $[\mathrm{M}-\mathrm{H}]^{-}$ion at $\mathrm{m} / \mathrm{z} 320$. So, the two compounds have the same molecular mass of 321.

The adducts of methylamine and 11-oxo-ODYA have the same UV spectrum as a 1:1 mixture of 5-( $N$-methylamino)tetradeca-5-en-8-yn-7-one and 6-( $N$-methylamino)tetradeca6-en-9-yn-8-one, with an absorbance maximum at $340 \mathrm{~nm}$ and a shoulder at $360 \mathrm{~nm}$. Absorbances at 2216, 2100 $(C \equiv C)$, and $1600(C=O) \mathrm{cm}^{-1}$ in the IR spectrum of the methylamine adduct with 11-oxo-ODYA are close to those at $2213(\mathrm{C} \equiv \mathrm{C})$ and $1598(\mathrm{C}=\mathrm{O}) \mathrm{cm}^{-1}$ in the spectrum of the 1:1 mixture of 5-( $N$-methylamino)tetradeca-5-en-8-yn7-one and 6-( $N$-methylamino)tetradeca-6-en-9-yn-8-one.

The ${ }^{1} \mathrm{H}-\mathrm{NMR}$ spectrum of the methylamine adduct with 11-oxo-ODYA shows two triplets at $2.20(J=7.7 \mathrm{~Hz})$ and $2.21(\mathrm{~J}=7.6 \mathrm{~Hz}) \mathrm{ppm}$ assigned to two methylene groups next to a double bond. Three triplets at $2.31(J=7.1 \mathrm{~Hz})$, $2.35(J=7.0 \mathrm{~Hz})$, and $2.36(J=7.4 \mathrm{~Hz}) \mathrm{ppm}$ are assigned to two methylene groups next to a triple bond and the methylene group next to the carboxyl group, respectively. The doublet at $2.98(J=5.2 \mathrm{~Hz}) \mathrm{ppm}$ and the singlet at 5.15 ppm are assigned to the $N$-methyl and a vinylic proton, respectively.

These data are in good agreement with the ${ }^{1} \mathrm{H}-\mathrm{NMR}$ spectrum of the 1:1 mixture of 5-( $N$-methylamino)tetradeca5-en-8-yn-7-one and 6-( $\mathrm{N}$-methylamino)tetradeca-6-en-9-yn8-one, with triplets at $2.19(J=7.8 \mathrm{~Hz}), 2.20(J=7.9 \mathrm{~Hz})$, $2.30(J=7.2 \mathrm{~Hz})$, and $2.32(J=7.0 \mathrm{~Hz}) \mathrm{ppm}$, a doublet at $2.97(J=5.4 \mathrm{~Hz}) \mathrm{ppm}$, and the singlet at $5.14 \mathrm{ppm}$.

The methylamine adduct with 11-oxo-ODYA is therefore identified as a mixture of 11-oxo-13-( $\mathrm{N}$-methylamino)octadeca-12-en-9-ynoic acid $\left(\mathrm{CH}_{3}\left(\mathrm{CH}_{2}\right)_{4} \mathrm{C}\left(\mathrm{NHCH}_{3}\right)=\mathrm{CHC}\right.$ $\left.(\mathrm{O}) \mathrm{C} \equiv \mathrm{C}\left(\mathrm{CH}_{2}\right)_{7} \mathrm{COOH}\right)$ and 11-oxo-9-( $N$-methylamino $)$ octadeca-9-en-12-ynoic acid $\left(\mathrm{CH}_{3}\left(\mathrm{CH}_{2}\right)_{4} \mathrm{C} \equiv \mathrm{CC}(\mathrm{O}) \mathrm{CH}=\mathrm{C}\right.$ $\left.\left(\mathrm{NHCH}_{3}\right)\left(\mathrm{CH}_{2}\right)_{7} \mathrm{COOH}\right)$. On the basis of the spectroscopic and chemical properties of the reaction products of 11-oxoODYA and methylamine or lipoxygenase, we propose that 11-oxo-ODYA is bound to amino groups of the protein, forming 11-oxo-13-(N-X)octadeca-12-en-9-ynoic acid and 11-oxo-9-(N-X)octadeca-9-en-12-ynoic acid chromophores, wherein $\mathrm{X}$ is the protein.

\section{DISCUSSION}

$\mathrm{Fe}(\mathrm{III})$ - lipoxygenase converts octadeca-9,12-diynoic acid (ODYA) into a novel product, 11-oxooctadeca-9,12-diynoic acid (11-oxo-ODYA), in the presence of oxygen. During this conversion the enzyme is eventually irreversibly inhibited.

At concentrations of $75 \mu \mathrm{M}$ ODYA and $2 \mu \mathrm{M} \mathrm{Fe}$ (III)lipoxygenase, $8-10$ molecules of 11-oxo-ODYA are estimated to be formed per molecule of lipoxygenase before all of the enzyme has become inactive. These results confirm earlier observations (Kühn et al., 1984) that, to some extent, triple bond analogues of natural fatty acids function as normal substrates. The most likely pathway that leads to the 

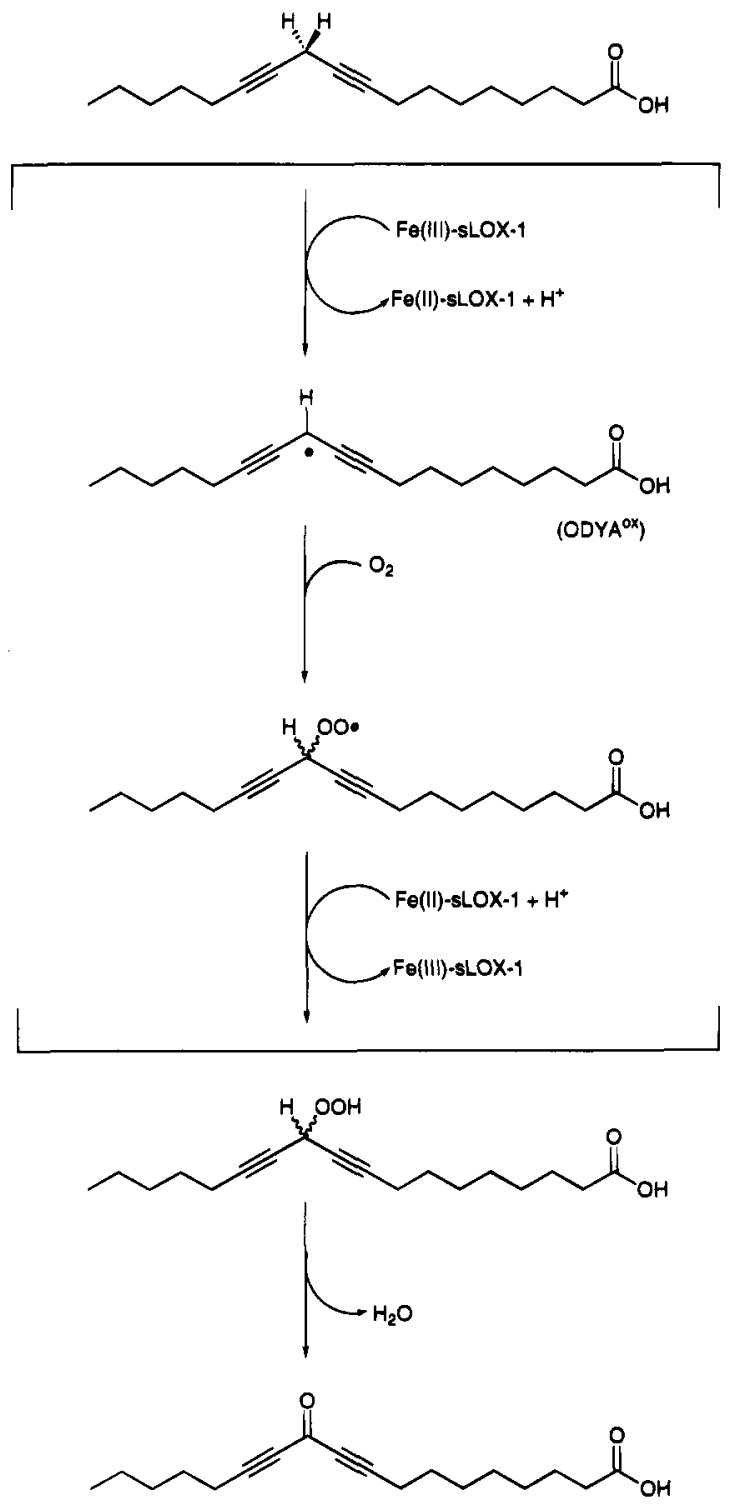

FIGURE 8: Proposed reaction scheme for the formation of 11-oxoODYA from ODYA and $\mathrm{O}_{2}$, catalyzed by $\mathrm{Fe}(\mathrm{III})$-lipoxygenase. $\mathrm{Fe}(\mathrm{II})$ - and $\mathrm{Fe}(\mathrm{III})$-sLOX-1 are $\mathrm{Fe}(\mathrm{II})$ - and Fe(III)-soybean lipoxygenase-1, respectively.

formation of 11-oxo-ODYA from ODYA and $\mathrm{O}_{2}$ is shown in Figure 8.

The fact that only $\mathrm{Fe}(\mathrm{III})$-lipoxygenase catalyzes the conversion of ODYA indicates that the first step in the reaction is the abstraction of, most likely, the pro-S hydrogen (Corey, 1987), leading to formation of the radical ODYA ${ }^{\text {ox }}$. Hydrogen abstraction is accompanied by reduction of $\mathrm{Fe}$ (III) to $\mathrm{Fe}$ (II). Since more than one molecule of product is formed per molecule of lipoxygenase, the iron cofactor must undergo several cycles of reduction and oxidation before the enzyme is inactivated. In analogy to the reaction with linoleic acid, we propose that $\mathrm{Fe}(\mathrm{II})$-lipoxygenase is reoxidized in an $\mathrm{O}_{2}$ addition step and that the first reaction product is 11-hydroperoxy-ODYA. The conversion of 11-hydroperoxy-ODYA into 11-oxo-ODYA involves a dehydration reaction. This dehydration may occur spontaneously, but could also be catalyzed by $\mathrm{Fe}$ (II)-lipoxygenase, analogously to the reaction of $\mathrm{Fe}$ (II)-lipoxygenase with HPOD in the formation of oxodienes. During this reaction $\mathrm{Fe}$ (II)lipoxygenase is oxidized to $\mathrm{Fe}$ (III)-lipoxygenase. This is corroborated by the observation that soybean lipoxygenase- 1 converts (11Z)-eicosa-11-en-14-ynoic acid into 11-hydroperoxy-(12E)-eicosa-12-en-14-ynoic acid and 11-oxo-(12E)eicosa-12-en-14-ynoic acid. The hydroperoxide was found to irreversibly inhibit lipoxygenase (Shieh et al., 1985).

As stated above, covalent binding of 11-oxo-ODYA to lipoxygenase does not result in inactivation of the enzyme. It is likely, therefore, that the covalent attachment of 0.89 molecule of 14,15-dehydroarachidonic acid to soybean lipoxygenase-1, detected by Corey and Park (1982), bears no relation to the inactivation process. Kühn et al. (1984) found no significant labeling of soybean lipoxygenase- 1 after its reaction with the ${ }^{14} \mathrm{C}$-labeled ETYA methyl ester. However, under the conditions that were used (lipoxygenase and inhibitor concentrations of 22 and $300 \mathrm{nM}$, respectively), the rate at which the secondary reaction occurs may have been very low. They reported that the inactivation of lipoxygenase was accompanied by the oxidation of a single methionine residue, but this could not be confirmed in later experiments (Höhne et al., 1991). Several authors have proposed that inactivation by triple bond analogues of natural substrates may occur via intermediate allenes (Downing $e t$ al., 1970; Corey \& Park, 1982; Corey et al., 1984; Corey, 1987). Our experiments do not support this hypothesis, because the only enzymatic product that we have detected is 11-oxo-ODYA, and not the 9- or 13-substituted compounds that would be expected to be formed from allenic structures. The absence of allenic intermediates was also confirmed by Shieh et al. (1985). Preliminary calculations on the electron distributions in the 1,4-diyn radical system indicate that the radical character is located almost exclusively on C3 and that allenic electron distributions are improbable. Therefore, it seems more likely that the triple bonds remain intact during the reaction. Further quantum mechanistic calculations are currently performed.

In true suicide reactions such as the reactions of serine proteases with chloromethyl ketones, or xanthine oxidases with allopurinol, the substrates are enzymatically converted into a product that binds covalently to the active site of the enzyme. In these cases, suicide inactivation occurs with a 1:1 stoichiometry. In contrast, the irreversible inactivation of lipoxygenase by ODYA occurs, on average, only after 8-10 turnover cycles. Compared to the suicide inhibitors mentioned above, ODYA is, therefore, rather ineffective. In view of the data that have been collected so far on the effect of triple bond analogues of natural fatty acids on lipoxygenase, it is proposed that the inactivation occurs after $8-10$ catalytic cycles of the enzyme and is caused by the hydroperoxy radical of the inhibitor. Studies on the nature of the reaction intermediates are in progress.

\section{ACKNOWLEDGMENT}

We gratefully acknowledge Mr. E. T. G. Lutz and Mr. E. $S$. van der Windt (Utrecht University) for recording of FTIR spectra and valuable discussions, Mr. D. J. van Unen (Utrecht University) for purification of the lipoxygenase, Dr. S. R. Martin (National Institute for Medical Research, London) for reading the manuscript, and Mr. P. H. Kruiska$\mathrm{mp}$ (Utrecht University) for measuring $2 \mathrm{D}{ }^{1} \mathrm{H}-\mathrm{NMR}$ spectra and valuable discussions.

\section{REFERENCES}

Adams, J., \& Gross, M. L. (1987) Anal. Chem. 59, 1576-1582. 
Blain, J. A., \& Shearer, G. (1965) J. Sci. Food Agric. 16, 373378.

Bligh, E. G., \& Dyer, W. J. (1959) Can. J. Biochem. Physiol. 37, 911-917.

Borel, C., Welti, D. H., Fernandez, I., \& Colmenares, M. (1993) J. Nat. Prod. 56, 1071-1077.

Boyington, J. C., Gaffney, B. J., \& Amzel, L. M. (1993) Science $260,1482-1486$.

Brandsma, L (1988) in Preparative Acetylenic Chemistry, 2nd ed., Elsevier, Amsterdam.

Chauvelier, J. (1954) Bull. Soc. Chim. Fr. 21, 743-739.

Corey, E. J. (1987) Pure Appl. Chem. 59, 269-278.

Corey, E. J., \& Munroe, J. E. (1982) J. Am. Chem. Soc. 104, 17521754.

Corey, E. J., \& Park, H. (1982) J. Am. Chem. Soc. 104, 17501752.

Corey, E. J., Lansbury, P. T., Cashman, J. R., \& Kantner, S. S. (1984) J. Am. Chem. Soc. 106, 1501-1503.

de Groot, J. J. M. C., Garssen, G. T., Vliegenthart, J. F. G., \& Boldingh, J. (1973) Biochim. Biophys. Acta 326, 279-281.

Dinwoodie, J. G., White, H. M., \& Day, W. J. (1962) J. Org. Chem. $27,327$.

Downing, D. T., Ahern, D. G., \& Bachta, M. (1970) Biochem. Biophys. Res. Commun. 40, 218-223.

Downing, D. T., Barve, J. A., Gunstone, F. D., Jacobsberg, F. R., \& Lie Ken Jie, M. (1972) Biochim. Biophys. Acta 280, 343347.

Finazzi Agro, A., Avigliano, L., Veldink, G. A., Vliegenthart, J. F. G., \& Boldingh, J. (1973) Biochim. Biophys. Acta 326, 462470.

Ford-Hutchinson, A. W., Gresser, M., \& Young, R. N. (1994) Annu. Rev. Biochem. 63, 383-417.

Hammerström, S. (1977) Biochim. Biophys. Acta 487, 517-519.

Höhne, W. E., Kojima, N., Thiele, B., \& Rapoport, S. M. (1991) Biomed. Biochim. Acta 50, 125-138.

Jensen, N. J., Tomer, K. B., \& Gross, M. L. (1985) J. Am. Chem. Soc. 107, 1863-1868.

Kühn, H., Holtzhütter, H.-G., Schewe, T., Hiebsch, C., \& Rapoport, S. M. (1984) Eur. J. Biochem. 139, 577-583.

Kühn, H., Hayess, K., Holtzhütter, H.-G., Zabolotsky, D. A., Mayagkova, G. I., \& Schewe, T. (1991) Biomed. Biochim. Acta $50,835-839$

Ludwig, P., Holzhütter, H.-G., Colosimo, A., Silvestrini, M. C., Schewe, T., \& Rapoport, S. M. (1987) Eur. J. Biochem. 168 , $325-337$.
Metler, T., Uchida, A., \& Miller, S. I. (1968) Tetrahedron 24, 4285-4297.

Migliorese, K. G., \& Miller, S. I. (1974) J. Org. Chem. 39, 843845.

Migliorese, K. G., Tanaka, Y., \& Miller, S. I. (1974) J. Org. Chem. $39,739-747$.

Minor, W., Steczko, J., Bolin, J. T., Otwinowski, Z., \& Axelrod, B. (1993) Biochemistry 32, 6320-6323.

Nuhn, P., Buge, A., Kohler, T., Lettau, H., \& Schneider, R. (1991) Pharmazie 46, 81-88.

Otsuki, T., Brooker, R. F., \& Funk, M. O. (1986) Lipids 21, 178181.

Schewe, T., Rapoport, S. M., \& Kühn, H. (1986) Adv. Enzymol. $58,191-272$

Schilstra, M. J., Veldink, G. A., Verhagen, J., \& Vliegenthart, J. F. G. (1992) Biochemistry 31, 7692-7699.

Schilstra, M. J., Veldink, G. A., \& Vliegenthart, J. F. G. (1993) Biochemistry 32, 7686-7691.

Schilstra, M. J., Veldink, G. A., \& Vliegenthart, J. F. G. (1994) Biochemistry 33, 3974-3979.

Shibata, D., Steczko, J., Dixon, J. E., Andrews, P. C., Hermodson, M., \& Axelrod, B. (1988) J. Biol. Chem. 263, 6816-6821.

Shieh, W.-R, Cacioli, P., \& Sih, C. J. (1985) Adv. Prostaglandin, Thromboxane, Leukotriene Res. 15, 303-306.

Siedow, J. N. (1991) Annu. Rev. Plant Physiol. Plant Mol. Biol. $42,145-188$.

Tomer, K. B., Crow, F. W., \& Gross, M. L. (1983) J. Am. Chem. Soc. 105, 5487-5488.

Van Aarle, P. G. M., de Barse, M. M. J., Veldink, G. A., \& Vliegenthart, J. F. G. (1991) FEBS Lett. 280, 159-162.

Van der Heijdt, L. M., Feiters, M. C., Navaratnam, S., Nolting, H.-F., Hermes, C., Veldink, G. A., \& Vliegenthart, J. F. G. (1992) Eur. J. Biochem. 207, 793-802.

Verhagen, J., Veldink, G. A., Egmond, M., Vliegenthart, J. F. G., Boldingh, J., \& Van der Star, J. (1978) Biochim. Biophys. Acta $529,369-379$.

Yamamoto, S. (1992) Biochim. Biophys. Acta 1128, 117-131.

BI950746N 